\title{
Defrauding Daughters Turning Deviant Wives? Reading Female Agency in The Merchant of Venice ${ }^{1}$
}

\author{
Nicoleta Cinpoeş \\ University of Worcester
}

\begin{abstract}
Brabantio's words "Look to her, Moor, if thou hast eyes to see: | She has deceived her father, and may thee" (Othello, 1.3.292-293) warn Othello about the changing nature of female loyalty and women's potential for deviancy. Closely examining daughters caught in the conflict between anxious fathers and husbands-tobe, this article departs from such paranoid male fantasy and instead sets out to explore female deviancy in its legal and dramatic implications with reference to Shakespeare's The Merchant of Venice. I will argue that Portia's and Jessica's struggle to evade male subsidiarity results in their conscious positioning themselves on the verge of illegality. Besides occasioning productive exploration of marriage, law and justice within what Morss (2007:183) terms "the dynamics of human desire and of social institutions," I argue that female agency, seen as temporary deviancy and/or self-exclusion, reconfigures the male domain by affording the inclusion of previous outsiders (Antonio, Bassanio and Lorenzo).
\end{abstract}

KEYWORDS: The Merchant of Venice; commodity/ commodification; subsidiarity; bonds/binding; marriage code versus friendship code; defrauding; deviancy; agency; conveyancing; (self)exclusion.

\footnotetext{
${ }^{1}$ My reading of The Merchant of Venice with a view to agency that reconfigures the social structures is indebted to and informed by Margaret S. Archer's work on structure and agency, especially in her Structure, Agency and the Internal Conversation (2003).
} 
The world of The Merchant of Venice constitutes a vast stage on which identities are shaped and performed, as Antonio's words imply: "I hold the world but as the world, Gratiano:| A stage where every man must play a part, $\mid$ And mine a sad one" (1.1.77-79). ${ }^{2}$ Within the space of one hundred lines that follow, Bassanio changes parts several times - from dearest friend to prodigal son returned, to lover in pursuit of his mistress, and, finally, to a new type of merchant - the investor - holding the key to Antonio's generosity: "[ANTONIO:] Within the eye of honour, be assured| My purse, my person, my extremest means | Lie all unlocked to your occasions" (1.1.136-138). Two acts later, Portia will show the same readiness to "lie" her own purse, person and means, only that in her case the beneficiary of such riches had to prove his worth in wit first, by "unlocking" the right casket, then in loyalty once ring-bound in marriage.

The two - Antonio and Portia - were brought into direct competition over Bassanio in the 2008 Royal Shakespeare Company production of the play not only during the trial scene (in which Portia appears disguised) but also openly at the ending of the performance (á la The Globe), which read Shakespeare's final stage direction "Exeunt" as "Dance". It is precisely the stage economics of this dance(d) finale that cues my reading of the The Merchant of Venice and my dipping into new economic criticism that follows in the present article.

"Deliberately only a kind of phantásia recapitulating the play," the dance - declared director Tim Carroll (9 April 2008) in the Director's Talk - was chosen for "neutrality [...] you could derive no sense of the production's attitude - I hope." This was true to begin with, as the stage was populated by the entire cast and the spectators had to work at reading both characters and choreography: against the magenta red stage one saw mostly grey suits (for men), a few splashes of colour (for women) and no Shylock. Once accustomed to the euphoric clapping and movements, one began to read (into) the dance routines. The exchange of gazes and the pairing of Antonio and Bassiano were sharply cut short by Portia, who took clear possession of her husband and by pulling him towards her and out

\footnotetext{
${ }^{2}$ All quotations from The Merchant of Venice are from the 1987 New Cambridge Shakespeare, edited by M.M. Mahood, and will henceforth be referenced parenthetically in the main text.
} 
of Antonio's reach. Antonio's physical exclusion from this triangle asserted heterosociality as the norm and could only be performed once he had been excluded from the socio-economics of the couple. In this production, Portia delivered the news that three of Antonio's "argosies [had] richly come to harbour suddenly" (5.1.276-277) suggesting that she was not ignorant either of their "riches" or of their "sudden return" but on the contrary, and deviously, that she was the one financing the whole affair.

Elsewhere on the stage, Jessica was "stolen" away from her familiars (Lancelot Gobbo and Tubal) by Lorenzo, an action which literalized the word used by Antonio in his mercy speech when sealing Shylock's fate (4.1.381). The fugitive couple slowly danced to the fore of the stage, still unsure of its position in the general sociodynamics of the RSC's Venice. Key to the pairing and re-pairing taking place on the stage, Shylock walked up from the auditorium and onto the stage. His strictly choreographed movements that cut the stage in depth separated the parties in the play; his temporary joining in the dance (with Antonio, or Portia, or Lancelot, or Jessica) reinforced his position, one of evading and being evaded. In the increasing frenzy, Jessica and Lorenzo strived to lock Shylock into their dance; this was only momentarily achievable because the economics of the dance required continuous exchanges of partners, and was deviant because the dance routine only allowed for one partner at a time.

In the remainder of this article I will focus on Portia and Jessica, the two daughters who are in comparable positions at the beginning of The Merchant of Venice, and follow their journeys into wifehood culminating with the inverted "mirror image" Carroll's 2008 stage production proposed, and will do so with an eye to both their individual agency and the external economic infrastructure that helps to shape their subjectivity and actions.

Portia, we learn from Bassanio's account to Antonio, is "In Belmont [...] a lady richly left | And she is fair" (1.1.160-161). What transpires from his brief account is that Bassanio sets more store by Portia's financial assets than by her beauty. He states her worth (beauty and "virtues") in financial terms ("nothing undervalued") and declares that winning her, had he but had "the means," would bring "thrift" and make him "fortunate" (1.2.160-175). Bassanio then delights in playing with double meanings, as when he employs 
"thrift" to mean success but also profit, and "fortunate" to mean luck but also acquiring a fortune. Antonio's use of "fortunes" in the following line, however, offers a complete disambiguation as he proceeds to decode it as "money," "commodity" and "credit" (1.2.177-179). In the following scene Nerissa initially talks of Portia's "good fortunes" as opposed to her "misery" only to qualify the pun a line later by talking about "mean happiness" and "superfluity" (1.2.4-7).

Like Bassanio, the competing suitors - the Moroccan Prince and the Prince of Aragon - make their choice of casket not so much by praising but by pricing Portia. Their speeches are replete with words related to coins and counterfeiting. Morocco comments on the inscription, "stampèd in gold" and "insculped upon" (2.7.56-57), and Aragon on "the stamp of merit," and their role in authenticating coins and coats of arms, respectively, being the warranty against "undeserved dignity" and "estates, degrees and offices | [...] derived corruptly" (2.9.39, 40-41). However, it is Bassanio who rejects the "gaudy gold" (3.2.101) as the mark of corruption. His lengthy anticorruption plea not only refers to a woman's beauty being turned into lightness (i.e., wantonness) when "supposed fairness" is "purchased by the weight" (3.2.89), but touches on wider economic issues: "Thus ornament is but the guilèd shore| To a most dangerous sea: the beauteous scarf | Veiling an Indian beauty; in a word.| The seeming truth which cunning times put on | To entrap the wisest" (3.2.97-101).

More than a rhetorical figure catering to the Elizabethan dislike of dark skin, ${ }^{3}$ the "Indian beauty," especially when accompanied by maritime vocabulary, signals the corruption of the English trade market by the infiltration of foreign gold, most likely of Spanish source, as Netzloff (2003:169) suggests, threatening to corrupt not only "the stability of the English domestic economy" but, more importantly, England's law, religion and colonial politics. ${ }^{4}$

${ }^{3}$ For more on Shakespeare's subversion and dismissal of this convention, see his sonnets 127 "In the old age black was not counted fair" and 130 "My mistress' eyes are nothing like the sun."

${ }^{4}$ Netzloff argues that, "[a]lthough an influx of specie was seen as essential to English commercial development, the economic effects of Spain's supersaturation with imported bullion were already evident in the late Elizabethan period; the influx of New World gold had caused massive inflation and a consumer economy wherein consumption could not keep up with inflated prices and devalued specie (Braudel, 
Contemplating the second casket, Bassanio then rejects the "common" silver as the base commercial currency and as the currency of betrayal, finally settling on lead. Though heavier in weight than gold and in paleness resembling silver, lead is "devoid of evident origin, production" and, most importantly, void of transactional or "circulation" value (Netzloff 2003:167), thus symbolic of Portia's evasive socio-economic status, somewhere between mercantile capital and rural gentry. ${ }^{5}$

As Netzloff (2003:167) argues, “despite [Portia's] suitors' commodification of her as the embodiment of value (Morocco), status (Arragon), or capital (Bassanio), or even [her] selfcommodification" following Bassanio's right choice of casket: "Myself, and what is mine, to you and yours | Is now converted" (3.2.166-167), Portia continues to escape the economic laws of Venice. Portia as "lord" of the mansion, "master" to servants, and "queen o'er" herself and all her assets are "converted" into the ring that binds Bassanio. In a sense, this wilful objectification deviates from the Venetian exchange rules in the same way as Shylock's bond, a pound of Antonio's flesh in exchange for 3,000 ducats for three months. Both the pound of flesh and the ring bear little intrinsic value; what makes their worth is the risk value bestowed upon or invested in them: it is literally Antonio's life in the first case, and Bassanio's in the latter. Should Bassanio "part from, lose or give the ring away" (3.2.172), his actions would return Portia's financial freedom by entitling her "my vantage to exclaim on you" (3.2.174),

Wheels of Commerce 174-175)" (2003:169). Bassanio's entire speech may be read as a commentary on the Anglo-Spanish rivalry as in early modern England this economic, national and religious competition was heavily "figured in languages of gender and sexuality." See Netzloff (2003:169).

${ }^{5}$ Several critics, such as Singh (2000) and Ross (2007), have argued that, far from being a fairy-tale world, Portia's Belmont is as commercial as Venice. Taking the debate a step further, Noemi Magri (2003:2) shakes the myth of the old aristocratic world of Belmont when arguing that Belmont, rather than being passed from generation to generation of aristocrats, may in fact have been built and its riches acquired from recent merchant activity not very unlike Antonio's: "In the 16th century, the Venetian nobility and rich merchants had started to invest their money in farms in the mainland more than in mercantile trade: this was due to the growing competition of foreign trade in the Americas. At the same time they built residences on the banks of the Brenta. In a few years, gardens and parks were planned, and the villas built in imitation of the Quattrocento or early Renaissance palaces on the Grand Canal became small courts where the nobility used to invite literary men, musicians, companies of players as they were used to do in their city palaces. [...] Belmont is [such] a place." 
in other words giving her the opportunity to denounce him, a contractual clause Bassanio agrees to: "be bold to say Bassanio's dead!" (3.2.185).

However odd this exchange of vows may seem, it was as binding as Shylock's bond. As Watt (2008:241, 243) argues, Portia's ring would have been recognisable to Shakespeare's audiences both as "a well-known method of transferring title to freehold land [livery of seisin]" and as a betrothal ring, but - significantly - not a "wedding ring, which did entail a moral (though not legal) transfer of property" (body + goods) but "was not passed until the marriage ceremony itself." Let us remember the sequence of events in act 3 scene 2: Portia gives in marriage the (morally binding) ring to Bassanio, who leaves for Venice having received the letter from Antonio, and the solemnisation and consummation of their marriage are to be completed upon his return: "First go with me to church, and call me wife, | And then away to Venice to your friend!| For never shall you lie by Portia's side| With an unquiet soul" (3.2.302305). ${ }^{6}$ Perhaps Bassanio's earlier line "there is such confusion in my powers" (3.2.177) following Portia's "oration" refers not only to his powers as "faculties," as Mahood, the CUP editor of the play explains in a footnote (1987:120, ff 177), but also, unwittingly, to his confused legal powers and prerogatives.

Equally replete with references to economics and ambiguous when it comes to morally versus legally binding are the homosocial relations and verbal exchanges. In the relationship between Antonio and Bassanio we read the same miscegenation between money and desire/love; purse and person are interchangeable in this play much like in Shakespeare's Twelfth Night, where (another) Antonio offers both his purse and himself to young Sebastian (in 3.3). Like "Cesario's offer to split his/her coffers with Antonio [when

\footnotetext{
${ }^{6}$ As Greer comments, "Elizabethan marriage had three distinct parts, the contract, the solemnisation and the consummation, which did not always occur in that order" (2007:57). While solemnisation was important in so far as it made a claim on the person (promised to be taken in marriage), consummation as validation of marriage in Elizabethan England was essential in so far as there was no point of return once consummation had taken place; without it, the marriage contract could still be disputed. Shakespeare comments at length on the intricacies of the three parts of marriage and their order in Measure for Measure. For more on marriage contracts in early modern England, see O'Hara (2000), Ross (2007) and Watt (2008).
} 
arrested]," Forman (2003:120) argues, Bassanio's offer to double the sum then pay it ten times over in court "is not adequate substitution for returning the purse that [his] Antonio needs." In The Merchant of Venice, Antonio's "indifference to divergent categories of value" (i.e., purse and person) is read by Bassanio with a difference. To Antonio, they are synonymous in the offer he makes; in accepting the offer, however, Bassanio divorces the purse from the person even when he admits that Antonio's purse gives him a new lease of life (pun intended): he is able both to pursue his personal desires and to purchase the necessary in order to do so.

This new life Bassanio seeks is that of an (independent) investor: he is eager to turn a profit (i.e., win Portia) on the capital from Antonio and readily invests the newly acquired capital (i.e., Portia's money) to save Antonio (in 4.1.84, 206-208). In this sense, he defrauds both his friend and his wife by precisely divorcing person from purse, and forfeits both homosocial friendship and heterosexual marriage. Bassanio, however, is not unique in his practice; Lancelot Gobbo, too, has little time for the "person"; his choice of employment is made on the largesse of the master's purse, and in doing so, he metonymically replaces the person of the master with his purse.

Unlike Antonio's act of giving, which (since unscripted) remains ambiguous both interpersonally and financially, Portia's giving (of herself and her assets) is legally and economically binding. In handing over her worldly possessions and herself to Bassanio, Portia reifies her position as an item of exchange, a mere commodity as Geary suggests (1984). But only temporarily and deviantly, I argue, because in her giving the ring and specifying the clause, Portia focuses on eliciting reciprocation from Bassanio, at once transforming the act of giving into an act of taking, as Watt suggests (2008:244). Instead of becoming a man of property (i.e., Portia and her assets) as he might have expected, Bassanio is appropriated (as husband) and also "propertied" (by the ring he wears): he is transformed into a commodity with exchange value (he had none before!), which can begin to generate interest on the Venetian market. Antonio will be the one cashing in on this twice: first in court (4.1), then in Belmont, at the end of the play.

What Bassanio forfeits, namely his loyalty to Portia, which he swears to give for Antonio, and potentially his property, as his wife 
and her assets are metonymically contained in the ring, Portia pays off by counterfeiting. This becomes her new form of deviancy: first by being "young doctor" Balthazar, who counterfeits the letter from Bellario and in court literalizes the law in order to save Antonio's life (another legal abuse much commented on), ${ }^{7}$ then by furnishing three of his argosies and counterfeiting the letter delivering the news to Antonio. In rescuing both Antonio's purse and person (both forfeited by Bassanio), old debts are cleared and in the process both men are commodified. Most importantly, in both cases Portia is defrauding by practising what Charles Ross (2007:98) calls "fraudulent conveyancing." But she has proved no stranger to that before: as a daughter, she claimed property that was, as Jordan and Cunningham (2007:12) argue, "her husband's under the terms of her father's will," cued Bassanio's choice of the right casket with a song (which warned him against trusting outer appearances and whose first three lines rhymed with "lead") ${ }^{8}$ and literally "curbed" her father's will when she devised the ring that bound Bassanio to her on her terms, not her father's. Holding "the continent and summary of [Bassanio's] fortune" (3.2.130), the scroll in the lead casket confirms that upon choosing the right casket Bassanio rightfully owns the fortune bound to Portia by her father:

You that choose not by the view

Chance as fair, and choose as true.

Since this fortune falls on you,

Be content and seek no new.

If you be well pleased with this,

And hold your fortune for your bliss,

Turn to where your lady is,

And claim her with a loving kiss. (3.2.131-138)

As Jordan and Cunningham (2007:12) argue, in binding Bassanio in her own terms with the ring, Portia signals that "although she has been traded as a chattel, she is a person" and, moreover, "a determined agent of her own fate" (Ross 2007:97).

\footnotetext{
${ }^{7}$ For critical takes on Portia's legal abuse in the trial scene, see Tucker (1976), Fisch (1974), Jordan (1982), McLean (1996), Sokol (1998), and recently Tiffany (2006) and Bilello (2007).

${ }^{8}$ Portia: "Tell me where is fancy bred,| Or in the heart, or in the head?| How begot, how nourished?" (3.2.63-65).
} 
Once betrothed, she preserves her agency and perseveres in being "deviant": she instructs Bassanio what to do and how much to pay for Antonio's life, then assumes judicial authority, and finally furnishes Antonio's argosies with her husband's money. Crucially, even after the ring is back in Bassanio's possession (5.1.254-257) and thus herself as well as all she has is, again, Bassanio's property, Portia still calls Belmont "my house" (5.1.273) and brings the news about Antonio's fortunes having harboured safely - by unveiling the content of the letter before it is even "unsealed" by Antonio (5.1.276) - precisely because she is yet to be "possessed" for the morally binding to become legally binding.

Unlike Portia, who is an unwilling commodity, Jessica actively markets herself as one and aims to enhance her exchange value from the very beginning. If Portia flirts with fraud as a daughter, Jessica is guilty of it twice: she elopes and she deliberately steals from Shylock. "My daughter! O my ducats! O my daughter!" (2.8.12-15) is a father's legitimate wailing upon being doubly defrauded. As Ross (2007:92) suggests, "in so far as she owed obedience to her father," Jessica "could be compared to a debtor, and her elopement to fraud against him." That this was a valid legal matter, the characters in the play make clear. Lorenzo knows that he can only obtain what Jessica steals and never inherit Shylock's fortune. Antonio is only too keen to remedy this situation: first, when accepting half of Shylock's wealth "in use" he vows "to render it | Upon [Shylock's] death unto the gentleman| That lately stole his daughter" (4.1.379-381; my italics) and second, when concluding his mercy speech, he forces Shylock to "record a gift,| Here in the court, of all that dies possessed | Unto his son Lorenzo and his daughter" (4.1.384-386).

Lorenzo's desire and wooing of Jessica, like Bassanio's of Portia, are openly associated with the pecuniary power of the ducat: "his affairs," he freely tells his friends, are "wife thieving" (2.6.23-24). Fully aware of it, Jessica uses this knowledge to make herself more marketable: in listing the riches she bestows on Lorenzo, she speaks in a tongue Lorenzo will both understand and appreciate. Her instructions to "take her" and "what gold and jewels she is furnished with" (2.4.30-31) is fulfilled to the letter: "I will [...] gild myself | With some more ducats" (2.6.50-51). Her words "[h]ere, catch this casket. It is worth the pains." (2.6.34) are transaction-like: Lorenzo 
has been reimbursed for his part of the bargain, namely helping Jessica to "[b]ecome a Christian and [his] loving wife" (2.3.20).

Jessica shares with Portia more than the "fraudulent conveyancing" (Ross 2007:92), the same props (a casket and a ring) and theatrical device (disguise), and the apparent willingness to submit to the will of her suitor. Despite their outward obedience, both women display a degree of agency (albeit subversive) which, I suggest, manifests precisely in their theatrical and financial initiative (or risk) both in defrauding their fathers and in deviating from their wifely part. Both are masters in theatrical counterfeiting: Portia in the trial scene, and Jessica in choreographing her elopement - "she has directed | How this is to be accomplished," Lorenzo confesses to his friends (2.4.30-31), and disguised herself as a "page." Even when married and their property had become their husbands', each of the women reasserts her position as owner. Portia still calls Belmont "my house" and disposes of money as if still hers (has it ever been?). All reports after Jessica's elopement state that she "spent in Genoa [...] one night four score ducats" (3.1.85) and that a sailor had a "ring" of Shylock's "daughter for a monkey" (3.1.93-94, my italics). Finally, in adopting male disguises, the women sacrifice their bodies, once again defrauding their husbands of what was rightfully theirs: the female bodies, which the women trade off (though Portia's and Nerissa's very bodies were bound in marriage through the ring giving in Belmont to Bassanio and Gratiano), and manliness, which the women temporarily assume. Unwittingly alluding to both these male anxieties, Gratiano confirms that the ring literalizes at once the marriage contract and female sexuality when he bawdily remarks upon retrieving his ring from the "doctor's clerk": "Well, while I live, I'll fear no other thing| So sore, as keeping safe Nerissa's ring" (5.1.306-307).

As Geary (1984:61) suggests, "Bassanio, Portia, Jessica, and Lorenzo share a sound grasp of what they have to gain from their marriages" and their exchanges of vows and promises are conducted in business "terms" (read: clauses and words). Like the men, the women are open about their self-interest: Portia is vocal both about her love for Bassanio and about her determination to have him as a husband; Jessica is equally clear that her interest is in salvation by becoming a Christian ('s wife). 
Theatrically, Portia and Jessica may be playing the same part; though similarly deviant as daughters, their later financial deviancy takes rather different paths. The part Portia plays in The Merchant of Venice is not just that of deus ex machina, that is, doctor Balthazar, who resolves both the Antonio-Shylock bond and the BassanioPortia ring-bond. She also plays deus ex mercato as she is the "portion" and the "porter" (i.e., carrier) of all men's financial security: Lorenzo's (and his letter), Antonio's (and his letter), Gratiano's (by endowing Nerissa), and Bassanio's "dear bought" (3.2.312) financial and personal freedom. Foolishly risky as Antonio's 3,000 ducats loan to Bassanio may have seemed (Shylock most certainly believed and said so), in the end it yields much "thrift."

However, it is not the kind of "thrift" either Bassanio or Antonio had in mind at the beginning of the play. Portia does not only prevent Shylock's attempt to cut out Antonio's heart but, as Geary (1984:66) suggests, "she cuts Bassanio out of Antonio's heart" (my italics); ironically, by the same ring with which she bound Bassanio, she binds Antonio. As in his transaction with Shylock at the beginning of the play, Antonio doesn't only accept the bond but becomes the bond. He eagerly offers his "soul upon the forfeit" (5.1.252), which Portia immediately accepts as "surety" (5.1.254) for her husband's loyalty and fidelity rather than any "renewed oath from her husband" (Geary 1984:67). Unwilling to leave the space of triangulation (one he occupied in Venice and aims to occupy in Belmont, too), Antonio willingly enters into another bond for Bassanio - "I dare be bound again" (5.1.253). Having bound earlier his money and his body, Antonio throws his soul into the bargain, literally giving his "all" for Bassanio. As Weisberg (2007:298) comments, Antonio seems "forever bound to stand in for Bassanio" (my italics). By offering himself as "surety" precisely "on the oath and ring that sanctify the direct obligation of The Marriage Code!" both in Venice (4.1) and in Belmont (in the final scene of the play), Antonio challenges the marriage code with what Geary calls (1984:66) "the men-before-women principle of the friendship code." In doing so he persists in his pursuit to stand between Portia and Bassanio: "My lord Bassanio, let him [Balthazar] have the ring.| Let his deservings and my love withal| Be valued 'gainst your wife's commandment" (4.1.445-447). 
Antonio is bound to embark on "an age of poverty" (4.1.267), as Geary suggest, but it is, I argue, only one of emotionally poverty. Perhaps the most important lesson Portia has taught Antonio is to divorce his purse from his person. Financially, Antonio has been "given" both "life and living" (5.1.286) and survives to be both "the merchant" and "the Jew" (4.1.170), thus embodying another type of miscegenation, an issue the play takes to task in the Lancelot Gobbo subplot. ${ }^{9}$ The law has ensured Antonio gains half of Shylock's wealth - conveniently, this is provided as ready goods and money (one thing Antonio did not have to begin with). Through his mercy speech (4.1.376-386) he ensures his legal right to usury by "use" of this wealth until Shylock's death, when it is to be signed over to Lorenzo, who would never have been regarded as Shylock's lawful heir either by the Venetian court or by the English one.

The lesson Portia teaches Bassanio is about their relationship which is not just emotional, as Ross (2007:100) infers, but also explicitly commercial. She outwits him at his own game: in giving the ring to Balthazar, Bassanio "has bankrupted himself" not so much "morally" - as Ross argues (2007:107, ff 18 ) - as financially. Much as Portia may have tried, through her ring-giving, to bind herself and all her assets, she only achieved it through rhetorical skills; legally, the ring remained binding only in property terms before the marriage was solemnised and consummated, as Portia herself acknowledges in 3.2. The two separate bonds she devises and achieves through the same ring leave the two men voiceless: "you have bereft me of all words," says Bassanio (3.2.175); "I am dumb," confesses defeated Antonio (5.1.279). As men and as merchants, they have been "outfaced" and "outsworn" by the "unlesson'd, unschool'd, unpractised" Portia (3.2.159) - another devious claim on

\footnotetext{
${ }^{9}$ It is in this sense that Lancelot disapproves, at length, of Jessica and Lorenzo's union. He sees it as a wholly unprofitable alliance in all respects, from social to religious and financial. With Jessica "damned both by father and mother," there is no hope for her redemption (not even a "bastard hope," should she be proven not to be her father's daughter and her mother a Christian). Moreover, marriage to a Christian would only extend the "blame" onto Lorenzo: "we were Christians enow before, e'en as many as could well live one by another" (3.5.16-17). Conversely, he is quick to dismiss Lorenzo's demand for "an answer [...] to the commonwealth" when the latter, commenting precisely on the kind of miscegenation Renaissance Venice (and England) explicitly forbade ("the getting up of the Negro's belly"), reveals that "the Moor is with child $[\ldots]$ by Lancelot" $(3 \cdot 5 \cdot 30-32)$.
} 
her part? - who, as Geary (1984:68) suggests, "ultimately proves herself the most adept business [person] of them all."

\section{References}

Archer, Margaret S. 2003. Structure, Agency and the Internal Conversation. Cambridge: Cambridge University Press.

Bilello, Thomas C. 2007. "Accomplished with What She Lacks: Law, Equity, and Portia's Con." Eds. Constance Jordan and Karen Cunningham. The Law in Shakespeare. Basingstoke: Palgrave Macmillan. 109-127.

Carroll, Tim 2008. Director's Talk. RSC, 9 April.

Fisch, Harold 1974. "Shakespeare and the Puritan Dynamic." Shakespeare Survey 27: 81-92.

Forman, Valerie 2003. "Material Dispossessions and Counterfeit Investments: The Economies of Twelfth Night." Ed. Linda Woodbridge. Money and the Age of Shakespeare: Essays in New Economic Criticism. New York: Palgrave Macmillan. 113-128.

Geary, Keith 1984. "The Nature of Portia's Victory: Turning to men in The Merchant of Venice." Shakespeare Survey 37: 55-68.

Greer, Germaine 2007. "Shakespeare and the Marriage Contract." Eds. Paul Raffield and Gary Watt. Shakespeare and the Law. Oxford, Portland: Hart Publishing. 51-64

Jordan, Constance and Cunningham, Karen 2007. "English Law in Shakespeare's Plays." Eds. Constance Jordan and Karen Cunningham. The Law in Shakespeare. Basingstoke: Palgrave Macmillan. 1-19.

Jordan, William Chester 1982. "Approaches to the Court Scene in The Bond Story: Equity and Mercy or Reason and Nature." Shakespeare Quarterly 33.1: 49-59.

Magri, Noemi 2003. "Places in Shakespeare: Belmont and Thereabouts." De Vere Society Newsletter, June, 1-9.

<url: http://www.deveresociety.co.uk/articles/essay-belmont.pdf>. Last accessed 7/02/2011.

McLean, Susan 1996. "Prodigal Sons and Daughters: Transgression and Forgiveness in The Merchant of Venice." Papers on Language and Literature 32: $45-62$.

Morss, John R. 2007. “'Desperately Mortal': Exclusion in Shakespeare's Legal Plays." Deakin Law Review 12/1: 181-191.

Netzloff, Mark 2003. "The Lead Casket: Capital, Mercantilism, and The Merchant of Venice." Ed. Linda Woodbridge. Money and the Age of 
Shakespeare: Essays in New Economic Criticism. New York: Palgrave Macmillan. 159-176.

O'Hara, Diana 2000. Courtship and Constraint: Rethinking the Making of Marriage in Tudor England. Manchester-New York: Manchester University Press.

Ross, Charles 2007. "Avoiding the Issue of Fraud: 4, 5 Philip \& Mary c.8 (the Heiress Protection Statute), Portia and Desdemona." Eds. Constance Jordan and Karen Cunningham. The Law in Shakespeare. Basingstoke: Palgrave Macmillan. 91-108.

Shakespeare, William 1987. The Merchant of Venice. Ed. M.M. Mahood. Cambridge: Cambridge University Press.

Singh, Jyotsna 2000. "Gendered 'Gifts' in Shakespeare's Belmont: The Economies of Exchange in Early Modern England." Ed. Dympna Callaghan. A Feminist Companion to Shakespeare. Oxford: Blackwell. 144159 .

Sokol, B.J. 1998. "Prejudice and Law in The Merchant of Venice." Shakespeare Survey 51: 159-173.

Tiffany, Grace 2006. "Law and Self-interest in The Merchant of Venice." Papers on Language and Literature 42: 384-400.

Tucker, E.F. 1976. "The Letter of the Law in The Merchant of Venice." Shakespeare Survey 29: 93-101.

Watt, Gary 2008. "The Law of Dramatic Properties in The Merchant of Venice." Eds. Paul Raffield and Gary Watt. Shakespeare and the Law. Oxford, Portland: Hart Publishing. 237-251.

Weisberg, Richard H. 2007. "The Concept and Performance of 'The Code' in The Merchant of Venice." Eds. Paul Raffield and Gary Watt. Shakespeare and the Law. Oxford, Portland: Hart Publishing. 289-298.

How to cite this note:

Cinpoes, Nicoleta. “Defrauding Daughters Turning Deviant Wives? Reading Female Agency in The Merchant of Venice." SEDERI 21 (2011): 133-146.

Author's contact: n.cinpoes@worc.ac.uk

Submission: 27/11/2010

Acceptance: 18/1/2011 